\title{
MANAJEMEN MEDIA RADAR SELATAN DALAM MENINGKATKAN JUMLAH PENGIKLAN
}

\author{
Qudratullah $^{1)}$ dan Hartina Fattah ${ }^{2)}$ \\ ${ }^{1,2}$ Ekonomi Perbankan Syariah, STAI Yapnas Jeneponto \\ 1,2,J1. Lanto Daeng Pasewang KM. 76, Tonrokassi, Tamalatea, Kabupaten Jeneponto, 92351 \\ E-mail : qudratullahrustam@gmail.com ${ }^{1)}$, thinafattah@gmail.com ${ }^{2}$
}

\begin{abstract}
ABSTRAK
Perkembangan media tidak terlepas dari iklan. Baik itu media elektronik, online bahkan media cetak yang merupakan salah satu jenis media yang cukup tua dibanding lainnya karena pendapatan sebuah media sebagian besar diporeh melalui iklan. Tidak heran jika manajemen media dalam meningkatkan jumlah pengiklan sangat perlu dilakukan dengan baik mengingat persaingan media juga semakin sengit. Penelitian ini bertujuan untuk mengetahui dan mengkaji lebih dalam manajemen sebuah media dalam meningkatkan jumlah pengiklan. Metode yang digunakan adaah kualitatif diartikan sebagai penelitian yang menghasilkan data deskriptif mengenai kata-kata lisan maupun tertulis, dan tingkah laku yang dapat diamati dari orang-orang atau objek yang diteliti. Sumber data diperoleh secara primer dan sekunder, di mana setelah data terkumpul peneliti melakukan kritik sumber untuk mengukur data yang telah dipeoleh sesuai dengan data yang diberikan oleh sumber data. Setelah itu, peneliti melakukan penafsiran dalam mengalanilisis data yang ada sebagai bagaian dari proses interpretasi. Penafsiran tersebut disajikan dalam narasi deskripti dalam bentuk rincian manajemen media yakni Radar Selatan. Berdasarkan hasil yang diperoleh penrliti, manajemen media Radar Selatan dalam meningkatkan jumlah pengiklan sama saja dengan media lainnya. Hanya saja, ada sedikit strategi yang dan jangkauan yang memiliki perbedan dengan media lainnya. Memasang iklan di Radar Selatan dapat melalui sistem offline atau langsung datang ke kantor atau melalui sistem online dengan mengunjungi situs yang telah disediakan. Dengan keberadaannya di salah satu wilayah bagian selatan Sulawesi Selatan, Radar Selatan kerap menjadi pilihan lembaga, individu dan pemerintah dalam beriklan. Selain karena memiliki pemasaran yang luas, Radar Selatan juga memiliki dta pembaca yang luas sebagaimana data menunjukkan total 15.975 pembaca dari delapan kabupaten/kota. Pembaca merupakan pria dengan jumlah $60 \%$ dan wanita dengan jumlah 40\%. Jika diklasifikasikan dalam kelompok usia, Radar Selatan banyak digemari oleh rentan usia 31-35 tahun, dari aspek pekerjaan banyak diminati oleh Karyawan/Pegawai negeri/TNI/ Polri sebanyak 35\% dan tingkat pendidikan dari kalangan Diploma sebanyak 48\%. Oleh karena itu, dengan pelanning hingga controling yang jelas terlihat bahwa sis lain dari manajemen medi Radar Selatan adalah segmentasi yang luas dengan perkembangan pesat meski jauh dari pusat ibu kota Provinsi Sulawesi Selatan.
\end{abstract}

Kata Kunci: Manajemen, Iklan, Media Radar Selatan

\section{PENDAHULUAN}

Media massa menjadi bagian yang kii tidak luput dari kehidupan manusia. Perkembangannya yang semakin pesat membuat media semakin berusaha menjadi media pilihan masyarakat dalam memperoleh informasi. Tidak hanya sebagai sumber informasi, media juga harus mampu berusaha menjadi bagian dari pilihan khalayak dalam mempromosikan sesuatu dalam bentuk iklan.

Dalam media cetak, iklan disajikan dalam bentuk gambar dengan ukuran varitiatif dengan harga yang juga bervariatif sesuai letak halaman, ukuran serta sajian warna. Iklan menjadi hal yang sangat penting bagi para pelaku media dalam meningkatkan ekonomi media.Periklanan merupakan pesan-pesan penjualan yang paling persuasif yang diarahkan kepada para calon pembeli yang paling potensial atas produk barang atau jasa tertentu dengan biaya yang semurah-murahnya (Jefkins, 1997)
Dalam persaingan iklan, setiap media harus mampu melakukan strategi dan manajemen yang efektif sehingga pengiklan tertarik memasang iklan di media tersebut. Dalam kegiatan periklanan, manajemen menjadi sangat penting kegunaannya. Karena manajemen merupakan instrumen utama untuk mencapai tujuan organisasi yang telah ditetapkan dan merupakan suatu sistem yang berfungsi untuk mengatur aktifitas seluruh elemen dalam suatu lembaga yang meliputi proses perencanaan, pengorganisasian, penganggaran, kepemimpinan, dan pengendalian.

Jika dalam proses manajemen yang kurang baik, maka akan menghasilkan pencapaian yang tidak sesuai target. Oleh karena itu, dengan penggunaan manajemen yang baik, maka akan memberikan peluang keuntungan yang lebih besar dan peluang risiko yang minim bagi pemasang iklan, biro iklan, organisasi, dan media seperti media cetak dan online. 
Saat ini, seiring perkembangan teknologi informasi dan komunikasi yang juga diikuti dengan menjamurnya media massa sehingga persaingan media juga semakin sengit. Media tidak lagi memiliki waktu lama untuk bersantai-santai menunggu pengiklan, tetapi medialah yang saat ini bersaing menawarkan space iklan di media dengan tawaran yang kreatif, murah, berkualitas, menarik dan sebagainya.

Hidup dan matinya bisnis media seperti medi cetak tergantung pada iklan. Oleh karena itu agar bisa menarik pemasang iklan atau pengiklan yang tinggi dan banyak di media, maka kegiatan pemasaran atau periklanan di media cetak dan online harus dikelola melalui kegiatan manajemen periklanan.

Di kabupaten Bulukumba terdapat beberapa media, yang selain menyampailkan informas juga terdapat kegiatan periklanan dan banyak yang sudah berpengalamalain dalam kegiatan manajemen periklanan dan dapat membuat medianya bertahan berkembang, dan maju. Tentu dengan kegiatan periklanan dan memiliki sistem pengelolaan periklanan yang sudah pasti mempunyai keunikan tersendiri.

Keberadaan media yang terus berkembang meski jauh dari lokasi ibu kota provinsi Sulawesi Selatan menjadi salah satu bukti bahwa perkembangan media melalui penyaluran informasi dan kepercayaan pengiklan masih menjad tumpuan hidupnya sebuah media. Media mampu berdaptasi dan menyesuaikan dengan kondisi di mana masyarakat tidak terlalu sadar media dan kegunaan selain wadah informasi tetapi juga saluran promosi yakni iklan.

\section{RUANG LINGKUP}

Dalam penelitian ini permasalahan mencakup:

1. Bagaimana manajemen media Radar Selatan dalam meningkatkan jumlah pengiklan?

2. Agar terfokus, penelitian ini memiliki batasan yakni terfokus pada manajemen media salah satu media yang ada di Kabupaten Bulukumba yaitu Radar Selatan dalam meningkatkan jumlah pengiklan.

3. Hasil penelitian akan menggambarkan manajemen media Radar Selatan dalam meningkatkan jumlah pengiklan dengan strategi dan manajemen tertentu. Secara khusus, sajian data yang detail akan dilakukan untuk melihat strategi dan manajemen yang berbeda dari media Radar Selatan.

\section{BAHAN DAN METODE}

Berikut disajikan badan teoritis dan metode dari penelitin ini

\subsection{Manajemen}

Pengertian manajemen Secara etimologis kata manajemen berasal dari bahasa Perancis Kuno ménagement, yang berarti seni melaksanakan dan mengatur. Sedangkan secara terminologis para pakar mendefinisikan manajemen secara beragam, diantaranya: Follet yang dikutip (Wijayanti, 2008) mengartikan manajemen sebagai seni dalam menyelesaikan pekerjaan melalui orang lain. Menurut Stoner yang dikutip dalam (Wijayanti, 2008) manajemen adalah proses perencanaan, pengorganisasian, pengarahan, dan pengawasan usaha-usaha para anggota organisasi dan penggunaan sumber daya-sumber daya manusia organisasi lainnya agar mencapai tujuan organisasi yang telah ditetapkan. Gulick dalam (Wijayanti 2008) mendefinisikan manajemen sebagai suatu bidang ilmu pengetahuan (science) yang berusaha secara sistematis untuk memahami mengapa dan bagaimana manusia bekerja bersama-sama untuk mencapai tujuan dan membuat sistem ini lebih bermanfaat bagi kemanusiaan.

Menurut (Terry, 2010) fungsi manajemen dapat dibagi menjadi empat bagian, yakni planning (perencanaan), organizing (pengorganisasian), actuating (pelaksanaan), dan controlling (pengawasan) :

1. Planning (Perencanaan) ialah penetapan pekerjaan yang harus dilaksanakan oleh kelompok untuk mencapai tujuan yang digariskan. Planning mencakup kegiatan pengambilan keputusan, karena termasuk dalam pemilihan alternatif-alternatif keputusan. Diperlukan kemampuan untuk mengadakan visualisasi dan melihat

2. Organizing (Pengorganisasian), Organizing berasal dari kata organon dalam bahasa Yunani yang berarti alat, yaitu proses pengelompokan kegiatankegiatan untuk mencapai tujuan-tujuan dan penugasan setiap kelompok kepada seorang manajer (Terry \& Rue, 2010). Pengorganisasian dilakukan untuk menghimpun dan mengatur semua sumber-sumber yang diperlukan, termasuk manusia, sehingga pekerjaan yang dikehendaki dapat dilaksanakan dengan berhasil.

3. Actuating (Pelaksanaan) merupakan usaha menggerakkan anggota-anggota kelompok sedemikian rupa, hingga mereka berkeinginan dan berusaha untuk mencapai tujuan yang telah direncanakan bersama. (Terry, 1993).

4. Controlling (Pengawasan) adalah penemuan dan penerapan cara dan alat utk menjamin bahwa rencana telah dilaksanakan sesuai dengan rencana yang telah ditetapkan

\subsection{Iklan Media Massa}

Secara umum iklan dapat diartikan sebagai bentuk kegiatan dalam mengkomunikasikan, menarik perhatian dan membujuk sebagian atau seluruh masyarakat untuk mengambil tindakan dalam merespon ide, barang, atau jasa yang dipresentasikan. Menurut Dewan Periklanan Indonesia (DPI, 2007) "Iklan merupakan pesan komunikasi pemasaran atau komunikasi publik tentang sesuatu produk yang disampaikan melalui suatu media, dibiayai oleh pemrakarsa yang dikenal, serta ditujukan kepada sebagian atau seluruh masyarakat." Arens dalam (Junaedi, 2013) mengungkapkan bahwa "Iklan sebagai struktur dan komposisi komunikasi informasi yang bersifat nonpersonal, umumnya dilakukan dengan berbayar yang dicirikan dengan persuasif, berisi tentang 
produk (barang, jasa, dan ide) yang diidentifikasikan sebagai sponsor melalui berbagai media."

Iklan adalah bagian dari bauran promosi (promotion mix) dan bauran promosi adalah bagian dari bauran pemasaran (marketing mix). Secara sederhana iklan didefinisikan sebagai pesan yang menawarkan suatu produk yang ditujukan kepada masyarakat lewat suatu media. Sedangkan periklanan (advertising) adalah segala biaya yang harus dikeluarkan sponsor untuk melakukan presentasi dan promosi nonpribadi dalam bentuk gagasan, barang atau jasa (Kotler, Amstrong, 2002).

Komponen-komponen dalam definisi tentang iklan yaitu : a) Suatu bentuk komunikasi. Secara aktual, iklan dibentuk dengan sangat terstruktur dari komunikasi verbal maupun non verbal yang disusun untuk memenuhi format waktu dan ruang yang spesifik yang ditentukan oleh pihak sponsor. b) Iklan diarahkan pada kelompok khalayak dan bukan ditujukan pada individu tertentu. Dikarenakan tujuan yang lebih mengarah pada kelompok inilah iklan lebih bersifat non personal atau merupakan bentuk dari komunikasi massa. (Junaedi, 2013)

Tujuan iklan yaitu: a) Sebagai media informasi Iklan ditujukan untuk menginformasikan suatu produk barang dan jasa kepada khalayak. Tidak hanya dalam produk tetapi juga hal lainnya. b) Untuk Mempengaruhi konsumen Iklan dapat mengarahkan konsumen untuk mengkonsumsi produk barang atau jasa tertentu, atau mengubah sikap agar sesuai dengan apa yang diinginkan oleh pengiklan. c) Untuk mengingatkan konsumen Iklan ditujukan agar konsumen selalu mengingat produk tertentu sehingga tetap setia mengkonsumsinya. (Junaedi, 2013).

Di media cetak, iklan disajikan dengan ukuran, dimensi dan tampilan yang beragam. Tentu dengan tarif yang juga beragam. Bahkan halaman dari posisi iklan juga berpengaruh terhadap biaya iklan yang akan dipasang. Meski dianggap biasa saja, iklna di media cetak tidaklah semurah apa yang dibayangkan. Bayangkan saja, untuk halamanan pertaman biaya iklannya bisa mencapai ratusan juta rupiah.

\subsection{Tahapan Penelitian}

Dijabarkan beberapa tahapan dalam melakukan penelitian ini

1. Jenis Penelitian

Jenis penelitian yang digunakan adalah metode kualitatif. Kualitatif diartikan sebagai penelitian yang menghasilkan data deskriptif mengenai katakata lisan maupun tertulis, dan tingkah laku yang dapat diamati dari orang-orang yang diteliti. (Moleong, 2001) dan (Bungin, 2007). Pendekatan diarahkan pada latar belakang objek dan individu tersebut secara holistik (utuh). Sifat dari jenis pelatihan ini adalah penelitian yang dilakukan dalam jumlah relatif kelompok kecil yang diwawancarai secara teliti dan mendalam. Informan diminta untuk menjawab pertanyaan umum, dan menentukan persepsi, pendapat dan perasaan tentang gagasan atau topik yang dibahas dan untuk menentukan arah penelitian. Kualitas hasil temuan dari penelitian kualitatif secara langsung tergantung pada kemampuan, pengalaman dari informan.

2. Lokasi Penelitian

Penelitian dilakukan di Kantor Radar Selatan di J1 Ahmad Yani,Ruko Caile Ujung Bulu, Tlp/fax (0413) 84311 Bulukumba.

3. Pendekatan penelitian yang dimaksud terdiri atas dua, yaitu pendekatan keilmuan dan pendekatan metodologi. Pendekatan keilmuan dalam penelitian ini adalah pendekatan ilmu manajemen serta teoriteori yang relevan dengan kajian manajemen. Sedangkan pendekatan metodologi yang dimaksud adalah metode penelitian kualitatif dengan ruang lingkup kajian yang spesifik pada Media Radar Selatan.

4. Sumber Data

Sumber data yang dibutuhkan untuk menunjang penelitian ini adalah: (1) Data Primer, yaitu data yang diperoleh atau dikumpulkan langsung dilapangan oleh orang yang melakukan penelitian atau yang bersangkutan memerlukannya. (Misbahuddin dan Hasan, 2013). (2) Data Sekunder, yaitu data yang telah dikumpulkan oleh pihak lain, bukan oleh peneliti sendiri untuk tujuan lain. Artinya peneliti adalah tangan kedua yang hanya mencatat, mengakses, atau meminta data tersebut (yang kadang sudah berwujud informasi) ke pihak lain yang telah mengumpulkannya di lapangan. (Istijanto, 2008).

5. Teknin Pengumpulan Data

Adapun teknik pengumpulan data yang dilakukan adalah dengan teknik wawancara, observasi, dokumentasi dan instrumen, sebagaimana uraian berikut:

1) Wawancara

Wawancara adalah percakapan dengan maksud tertentu, percakapan itu dilakukan oleh dua pihak, yaitu pewawancara (interviewer) yang mengajukan pertanyaan dan yang diwawancarai (interviewer) yang memberikan jawaban atas pertanyaan yang diajukan (Arikunto, 2006). Jenis wawancara yang digunakan adalah wawancara mendalam (indepth interview), yaitu jenis wawancara untuk menggali keterangan secara lebih komprehensif mengenai permasalahan yang ditanyakan/ (Arikunto, 2006). Wawancara dilakukan berdasarkan pedoman wawancara yang dibuat sebelumnya, dimana penulis menanyakan halhal yang menurut penulis penting untuk diketahui sebagai tambahan data untuk dianalisis. Pertanyaan-pertanyaan yang diajukan dalam wawancara bersifat pertanyaan terbuka, dimana penulis tidak memberikan jawaban seperti yang tersedia dalam kuesioner.

2) Observasi 
Beberapa informasi yang diperoleh dari metode observasi adalah ruang (waktu dan tempat), pelaku, kegiatan, objek, perbuatan, kejadian atau peristiwa berkenaan dengan objek penelitian. Tujuan observasi adalah untuk menyajikan gambaran objektif perilaku atau kejadian guna menjawab permasalahan penelitian dan membantu mengerti perilaku subjek penelitian dan untuk evaluasi terhadap aspek tertentu dengan melakukan umpan balik terhadap penilaian tersebut.

3) Dokumentasi

Sejumlah besar fakta dan data tersimpan dalam bahan yang berbentuk dokumentasi. Sifat utama data ini tidak terbatas pada ruang dan waktu sehingga memberi peluang peneliti untuk mengetahui hal-hal yang pernah terjadi di waktu silam. Data dokumentasi yang dimaksud terutama bersumber dari arsip Media Radar Selatan, grafik/foto peristiwa dan dokumen relevan lainnya.

6. Instrumen

Penelitian kualitatif dilakukan pada kondisi alamiah dan peneliti adalah instrument kunci (Bungin, 2003) Kedudukan peneliti sebagai instrument dalam penelitian kualitatif adalah sebagai perencana, pelaksana pengumpulan data, analisis dan penafsir data serta pelapor hasil penelitian (Moleong, 2001). Dengan maksud demikian, digunakan alat pengumpulan data berupa petunjuk wawancara (interview guide), catatan lapangan (fieldnote) dan alat rekam peristiwa seperti videokamera dan tape recorder.

7. Metode Analisis Data

Analisis data dalam penelitian ini dilakukan secara induktif, sesuai dengan alur penelitian kualitatif (Bungin, 2003) Adapun tahapan analisis data disesuaikan dengan fokus masalah yang diteliti dan temuan data lapangan sebagaimana berikut.

1) Reduksi data

Reduksi data adalah proses memilih dan menyederhanakan, mengabstraksikan, memfokuskan dan mengubah data kasar yang muncul dari catatan-catatan lapangan. Reduksi data dimaksudkan untuk menentukan data sesuai dengan fokus penelitian.

2) Penyajian data

Penyajian data adalah metode mengorganisir suatu data yang memudahkan peneliti untuk membuat kesimpulan atau tindakan yang diusulkan. Sajian data pada penelitian ini adalah proses memilih data yang disesuaikan dengan fokus permasalahan dan tujuan penelitian.

3) Penyimpulan data

Konklusi atau kesimpulan yaitu penjelasan tentang makna data dalam suatu konfigurasi yang menunjukkan alur kausalnya. Pada tahap ini keseluruhan permasalahan dijawab sesuai dengan kategori data dan masalahanya dan menunjukkan kesimpulan yang mendalam dari temuan data penelitian.

8. Uji Keabsahan Data

Pengecekan keabsahan data penelitian ini dilakukan melalui tahap pengecekan kredibilitas data dengan teknik triangulation yaitu mengecek balik derajat kepercayaan suatu informasi yang diperoleh dengan triangulasi sumber, metode dan teori (Moleong, 2001). Adapun model trianggulasi yang digunakan adalah memberchek, yaitu proses pengecekan data yang diperoleh peneliti kepada pemberi data. Tujuan memberchek adalah untuk mengetahui seberapa jauh data yang diperoleh sesuai dengan apa yang diberikan oleh pemberi data. Apabila data yang ditemukan disepakati oleh para pemberi data berarti datanya telah valid, sehingga semakin kredibel dan dapat dipercaya. Selain itu salah satu cara paling penting dalam uji keabsahan hasil peneltian adalah dengan melakukan triangulasi, peneliti, metode, dan teori sebegai berikut:

1) Triangulasi kejujuran peneliti, yaitu dilakuka untuk menguji kejujura, subjektifitas, dan kemampuan merekam data oleh peneliti di lapangan. Hal tersebut dilakkan dengan cara meminta bantuan peneliti lain melakukan pengecekan langsung, wawacara ulang, serta merekam data dilapangan.

2) Triangulasi dengan sumber data, yaitu membandingkan dan mengecek derajat kepercayaan suatu informasi yang diperoleh secara waktu yang berbeda dalam metode kualittaif dengan cara: (a) membandingkan dat hasil pengamatan data dengan hasil wawancara, (b) membandingkan apa yang dikatakan orng didepan umum dengan apa yang dikatakan secara pribadi, (c) membandingkan apa yang dikatakan orang-orang tentang situasi penelitian dan apa yang di kataka sepanjang waktu, (d) membandingkan hasil wawancara dengan isi suatu dokumen yang berkaitan, (e) penilaian hasi penelitian dilakukan informan, (e) mengoreksi kekeliruan oleh sumber data, dan (f) menilai kecukupan data yang dikumpulkan. (Bungin, 2008).

\section{PEMBAHASAN}

Berkut dijabarkan hasil dan pembahasan dari penelitian ini

\subsection{Profil Kabupaten Bulukumba}

Kabupaten Bulukumba merupakan wilayah paling selatan dan timur Sulawesi Selatan dengan topografi berupa dataran rendah dan bukit bergelombang. Bulukumba merupakan daerah pantai di mana bagian selatan Selat Makassar dan utara Teluk Bone. Karena letaknya yang strategis, Bulukumba juga merupakan 
daerah persinggahan sebelum menuju ke Kabupaten Kepulauan Selayar di Pulau Selayar dan Kabupaten Sinjai.

Bulukumba juga dikenal sebagai Butta Panrita Lopi (Tanah para ahli pembuat perahu) yang berjarak $152 \mathrm{~km}$ dari Kota Makassar, Ibu Kota Provinsi Sulawesi Selatan. Waktu tempuh antara 2,5 jam sampai 3,5 jam. Karena itu, Bulukumba dikenal secara nasional maupun di mancanegera sebagai daerah industri kapal Pinisi..

Bulukumba juga mempunyai potensi alam berupa pertanian tanaman pangan, perkebunan, dan perikanan. Dengan potensi yang dimilikinya, Bulukumba merupakan daerah yang potensi ekonominya cukup besar untuk pengembangan usaha.

Masyarakat Bulukumba sebanyak 450 ribu jiwa, merupakan masyarakat majemuk yang terdiri dari berbagai suku dan etnis yang didominasi suku Bugis dan Makassar.

Bulukumba, sebagai daerah yang berada paling selatan Sulsel, berbatasan dengan daerah Bantaeng, Sinjai dan Selayar. Bahkan di bagian Barat dan Utara, Bulukumba berbatasan dengan Kabupaten Gowa, Jeneponto dan Takalar.

Sebagai kota yang tumbuh sangat pesat, Bulukumba kini memiliki pusat perbelanjaan (Mall) yang menggandeng Departmen Store Ramayana dan Supermarter Robinson. Sejumlah penginapan dan hotel juga tumbuh subur. Begitu juga dengan pusat-pusat niaga lainnya. Disamping itu, di Kota Butta Panrita Lopi ini juga terdapat sejumlah bank, mulai dari BRI, BNI, Bank BPD, Bank Syariah, serta lembaga pembiayaan seperti Adira, Kredit Plus, Amanah, dan lain sebagainya. (Radar Selatan, 2018)

\subsection{Manajemen Iklan Media Radar Selatan

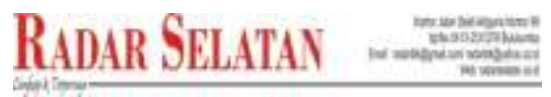

\section{Gambar 1. Header Radar Selatan}

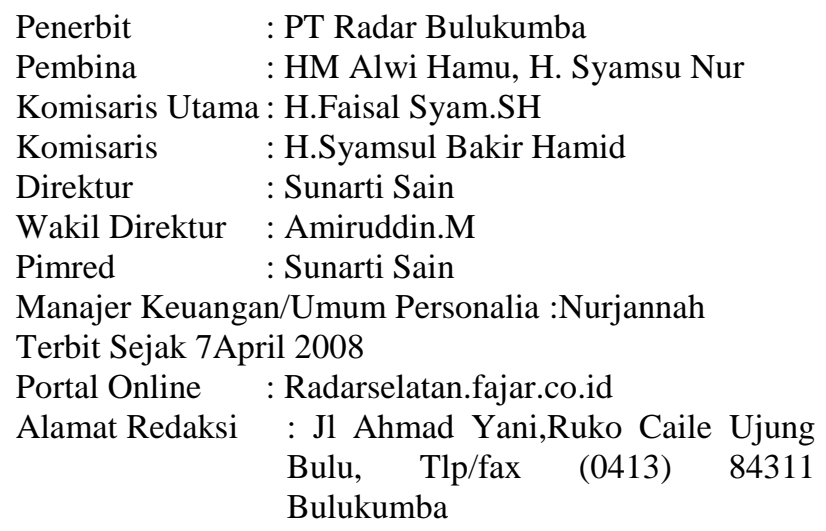

Perwakilan Jakarta: Graha L9 Fajar Group J1 Kebayoran Lama Pal 7 No 17 Jakarta 12210 tlp (021) 5322632.
Perwakilan Makassar: Graha Pena Lantai 4 Jalan Urip Sumoharjo No 20 Makassar, Sulsel. Telepon (0411) 441441

1. Sasaran Pembaca dan Keunggulan

Keunggulan Radar Selatan dibanding dengan koran lain yang beredar di Wilayah Selatan-selatan Sulawesi Selatan, adalah tiba lebih pagi di tengan pembacanya dan penyebarannya sangat luas mulai dari Kota Makassar, Gowa, Takalar, Jeneponto, Bantaeng, Sinjai, Selayar dan berkantor pusat di Bulukumba. Sebagai Koran penyalur aspirasi masyarakat Selatan-selatan, Radar Selatan telah menerobos masuk hingga ke pelosok desa di wilayah peredarannya.

Keunggulan lain Radar Selatan lebih fokus pada penyajian berita-berita lokal wilayah peredarannya, tanpa mengabaikan berita-berita regional, nasional dan internasional. Radar Selatan dibaca kalangan eksekutif, profesional, pendidikan, kalangan ekonomi menengah dan atas, sehingga promosi Anda lebih efektif dan efesien. Saatnya berkomunikasi melalui Harian Radar Selatan dan beriklan melalui Radar Selatan.

Secara umum, manajemen media Radar Selatan dalam meningkatkan jumlah pengiklan sama saja dengan media lainnya. Hanya saja, ada sedikit strategi yang dan jangkauan yang memiliki perbedan dengan media lainnya. Memasang iklan di Radar Selatan dapat melalui sistem offline atau langsung datang ke kantor atau melalui sistem online dengan mengunjungi situs yang telah disediakan.

Dalam manajemen Radar Selatan, kerap kali melakukan rapat perencanaan sebagai bagian dari perumusan pencapaian target. Setiap bagian ada program target iklan yang telah ditentukan. Promosi dan target dengan penghasilan per tahun menjadi hal yang penting dilakukan dalam proses kerja Radar Selatan. Olehnya strategi keunggulan harus matang dilakukan tanpa harus merasa kecil dengan pesaing lainnya. Untuk mencapai target yang telah ditentukan, sistem melobi pelanggan dan pengiklan baru dilakukukan dengan mempersuasif para calon pengiklan untuk memasang iklan di Radar Selatan.

Meski ptidak begitu sengit, Radar Selatan masih percaya diri sebagai pilihan iklan terbaik di bagian Selatan Sulawesi Selatan untuk cetak. Tetapi untuk online, Radar Selatan mengaku harus banyak memasang strategi karena banyaknya media online sebagai pesaing yang tidak boleh dianggap enteng sekalipun itu media baru.

Radar Selatan kerap melakukan kerja sama dengan pemerintah untuk pemasangan iklan. Sehingga dapat disimpulkan bahwa Pemerintah Daerah termasuk DPRD juga merupakan pengiklan tetap di Radar Selatan. Selatin itu, target untuk pengusaha kecil ke bawah juga ada karena Radar Selatan juga memberikan penawaran iklan yang murah dibandig media lainnya. Hal tersebut menjadi salah satu strategi mengingat lokasi Radar Selatan yang bukanlah terletak di ibu kota provinsi. 
Space ada juga untuk iklan kontrak seperti perusahan besar dari jangka setengah tahun hingga setahun. Keuntungan juga banyak didapatkan dari pengiklan iklan perusahaan besar dengan perjanjian tertentu mengenai dimensi iklannya. Iklan Radar Selatan terus bertumbuh seiring dengan jumlah pengeluaran yang juga memaksa harus banyak dikeluarkan tetapi tetap denga target yang realistis. Bedanya dengan media lain, radar selatan lebih merakyat karena media lokal. Konten lokal dan lebih menjadi pilihan karena memiliki factor kedekatan (proximity).

Evaluasi selalu dilakukan setiap bulan untuk mengetahui pencapaian selama waktu tersebut. Radar Selatan juga kerap membuat event untuk mempromosikan media Radar Selatan seperti Jamboree Jurnalistik, seminar dan selalu terbuka jadi media partner sebagai bagian dari promosi.

Dengan keberadaannya di salah satu wilayah bagian selatan Sulawesi Selatan, Radar Selatan kerap menjadi pilihan lembaga, individu dan pemerintah dalam beriklan. Selain karena memiliki pemasaran yang luas, Radar Selatan juga memiliki dta pembaca yang luas sebagaimana data berikut:

2. Data Pembaca \& Wilayah Peredaran Koran

$\begin{array}{lrc}\text { Makassar, } & 2.200 & \text { pembaca } \\ \text { Gowa, } & 1.800 & \text { pembaca } \\ \text { Takalar } & 1.700 & \text { pembaca } \\ \text { Jeneponto } & 2.100 & \text { pembaca } \\ \text { Bantaeng } & 1.500 \text { pembaca } \\ \text { Sinjai } & 2.200 \text { pembaca } \\ \text { Selayar } & 975 \text { pembaca } \\ \text { Bulukumba } & 3.500 \text { pembaca } \\ \text { Total } & 15.975 \text { pembaca }\end{array}$

Dari isi halaman, Radar Selatan tidak hanya mewakili satu segmentasi juga teteapi beragam segmentasi sehingga para pembaca tidaklah dikualifikasikan hanya kepada pembaca kelas menengah ke atas atau kelas menengah ke bawah. Sebagai gambaran, berikut halaman dan rubrik dari Radar Selatan:

\section{Halaman \& Rubrikasi}

SESI I :

1. Halaman Utama

2. Metro I

3. Metro II

4. Daerah

5. Politik

6. Pendidikan

7. Sportif \& Entertainment

8 . Jendela Desa

SESI II :

9. Sinjai - Selayar

10.Sambungan

11.Ekonomi

12.Politik

\section{Profil Pembaca}

Pembaca Rada Selatan merupakan pria dengan jumlah $60 \%$ dan wanita dengan jumlah $40 \%$. Jika diklasifikasikan dalam kelompok usia, Radar Selatan banyak digemari oleh rentan usia 31-35 tahun, dari aspek pekerjaan banyak diminati oleh Karyawan/Pegawai negeri/TNI/ Polri sebanyak 35\% dan tingkat pendidikan dari kalangan Diploma sebanyak $48 \%$.

Usia:

$$
\begin{array}{ll}
* 16-20 & 5 \% \\
* 21-25 & 11 \% \\
* 26-30 & 19 \% \\
* 31-35 & 23 \% \\
* 36-40 & 21 \% \\
* 41-45 & 14 \% \\
* 46-50 & 5 \% \\
* 51- & 2 \%
\end{array}
$$

Pekerjaan:

$\begin{array}{ll}\text { Pelajar } & 9 \% \\ \text { Mahasiswa } & 7 \% \\ \text { Akademisi } & 12 \% \\ \text { Petani/pedagang } & 20 \% \\ \text { Ibu rumah tangga } & 19 \%\end{array}$

Karyawan/Pegawai negeri/TNI/ Polri $35 \%$

Lain-lain $\quad 8 \%$

Tingkat Pendidikan:

$\begin{array}{lc}\text { SLTP } & 12 \% \\ \text { SLTA } & 14 \% \\ \text { Diploma } & 48 \% \\ \text { Sarjana } & 26 \%\end{array}$

\section{Manajemen Fajar group/Jawa Pos Group}

Harian Radar Selatan dikelola secara profesional oleh manajemen PT Radar Bulukumba, sebuah perusahaan di bawah bendera Fajar Group/Jawa Pos Group. Manajemen ini terbukti berhasil mengelola lebih dari 180 penerbitan Koran dan majalah di 26 provinsi di Indonesia.

\section{Profesional \& Pro Bisnis}

Harian Radar Selatan dikelola para wartawan dan karyawan profesional, berusia muda, dinamis dan sarat dengan idealisme. Jajaran direksi adalah orang-orang sukses mengelola Koran serupa yang sekarang maju pesat.

Dengan penuh cita-cita dan optimisme, pengelola Harian Radar Selatan yakin Koran ini akan ada di barisan depan industri pers di Sulawesi Selatan. Selain kaya dengan idealisme, Harian Radar Selatan menampilkan informasi-informasi bisnis dan ekonomi terkini, baik dalam skala lokal, regional maupun nasional bahkan internasional.

\section{Advertorial}


Harian Radar Selatan menyediakan halaman/rubrik advertorial baik berwarna maupun hitam putih dengan sajian informasi secara detail tentang produk/jasa, atau perusahaan, lembaga dan lain-lain.

Dengan sajian advertorial produsen dapat berbicara lebih mendalam, lebih rinci dan sistimatis dan lebih obyektif kepada pembaca tentang produk yang dihasilkannya. Keuanggulan lain advertorial, dapat dibaca sebagai berita dan menambah pengetahuan serta hiburan karena penyajiannya menarik dengan bahasa yang komunikatif.

8. Spesifikasi

Ukuran Junior Broadsheet : $540 \mathrm{~mm} \quad \mathrm{x} 7$ kolom

9. Halaman

$\begin{array}{ll}\text { Edisi setiap hari } & 12 \text { halaman } \\ & 4 \text { halaman warna } \\ \text { Jumlah kolom } & 7 \text { kolom } \\ \text { Periode Terbit } & 6 \text { kali sepekan }\end{array}$

10. Segmentasi

$\begin{array}{ll}\text { Berita Internasional } & 1 \% \\ \text { Berita Nasional } & 5 \% \\ \text { Berita Regional Sulselbar } & 10 \% \\ \text { Berita Lokal } & 85 \%\end{array}$

11. Tarif Iklan

$\begin{array}{ll}\text { FC } & \text { Rp 25.000/mm/kolom } \\ \text { BW } & \text { Rp20.000/mm/kolom } \\ \text { Iklan Mungil } & \text { Rp35.000/kolom/terbit } \\ \text { Iklan Baris } & \text { Rp 1000/baris/terbit } \\ \text { Sponsorship FC } & \text { Rp 10.000.000/halaman/terbit } \\ \text { Sponsorship BW } & \text { Rp 7.500.000/halaman/terbit }\end{array}$

12. Daftar Harga Iklan Paket

Seperti media pada umunya, Radar Selatan juga kerap menjalin kerja sama dengan beberapa perusahaan, lemabaga dan instansi pemerinta maupun swasta dalam memasang iklan. Selain tarif varian iklan di atas, Radar Selatan juga menyediakan tarif paket iklan sebagai berikut:

Untuk Halaman Warna (FC) :

1) Ukuran 4 Kolom $x 270$ mm x 26 kali Rp 10.000.000

2) Ukuran 3 Kolom x 150 mm x 26 Kali Rp 8.000.000

3) Ukuran 2 Kolom $x 100$ mm x 26 Kali Rp 7.500.000

4) Ukuran Banner halaman satu (7 kolom $x 50 \mathrm{~mm}) \times 26$ kali Rp 10.000.000,-

5) Ukuran Banner halaman belakang(7 kolom x 50 mm)x 26 kali Rp 8.000.000,-

Untuk Halaman Hitam Putih (BW) :

1) Ukuran 4 Kolom $x 270$ mm x 26 Kali Rp 5.000.000

2) Ukuran 3 Kolom $x 150$ mm x 26 Kali Rp 4.000.000Ukuran 2 Kolom x 100 mm x 26 Kali Rp 3.000 .000
3) Ukuran Banner halaman dalam (7 kolom x $50 \mathrm{~mm}$ ) kali Rp 5.000.000,-

\section{Informan Penelitian:}

Nurannah: Menejer Keungan Radar Selatan Anjar S. Masiga: Wartawan yang juga kerap menjadi bagian dari pihak penawar iklan kepada pelanggan dengan sistem yang sesuai dengan aturan media.

\section{KESIMPULAN}

Berdasarkan hasil penelitian, manajemen media Radar Selatan dalam meningkatkan jumlah pengiklan, terlebih dahulu dilakukan rapat perencanaan sebagai bagian dari perumusan pencapaian target. Radar Selatan kerap melakukan kerja sama dengan pemerintah untuk pemasangan iklan. Selatin itu, target untuk pengusaha kecil ke bawah juga ada karena Radar Selatan juga memberikan penawaran iklan yang murah dibandig media lainnya. Space ada juga untuk iklan kontrak seperti perusahan besar dari jangka setengah tahun hingga setahun.Hal tersebut menjadi salah satu strategi mengingat lokasi Radar Selatan yang bukanlah terletak di ibu kota provinsi. Bedanya dengan media lain, radar selatan lebih merakyat karena media lokal. Konten lokal dan lebih menjadi pilihan karena memiliki faktor kedekatan (proximity). Evaluasi selalu dilakukan setiap bulan untuk mengetahui pencapaian selama waktu tersebut. Radar Selatan juga kerap membuat event untuk mempromosikan media Radar Selatan seperti Jamboree Jurnalistik, seminar dan selalu terbuka jadi media partner sebagai bagian dari promosi.

\section{SARAN}

berdasarkan hasil penelitian dan kesimpulan, penulis memberikan saran sebagai bahan masukan dalam topik penelitian ke depannya yang memiki kesamaan tujuan yang sama. Untuk Radar Selatan, perlu dilakukan pembaharuan cara kerja dan tampilan iklan yang lebih nyentrik yang dapat membedakan dengan media lain. Contoh dengan penyajian iklan karikatur dengan warna yang beragam sehingga semakin menarik perhatian. Kedua, perlu dilakukan penelitian lanjutan dengan pendekatan berbeda dan skal yang lebih luas untuk melihat manajemen suatu media dalam meningkatkan jumlah pengiklan.

\section{DAFTAR PUSTAKA}

Jefkins, Frank, 1997, Periklanan, Jakarta: Erlangga.

Wijayanti, 2008, Manajemen, Jogjakarta: Mitra Cendekia Press.

Terry, George dan Leslie W. Rue, 2010, Dasr-Dasar Manajemen, Jakarta: PT. Bumi Aksara

Terry, George R., 1993, Prinsip-prinsip Manajemen, Bumi Aksara, Jakarta.

Dewan Periklanan Indonesia, 2007. 
Junaedi, Fajar, 2013, Jurnalisme Penyiaran dan Reportase Televisi. Jakarta: Kencana Prenada Media Group.

Moleong, Lexy J, 2001, Metodologi Penelitian Kualitatif, Bandung: Remaja Rosdakarya.

Bungin, Burhan, 2007, Penelitian Kualitatif: Komunikasi, Ekonomi, Kebijakan Publik dan Ilmu Sosial lainnya, Jakarta:Putra Grafika.

Amstrong, Gary dan Philip, Kotler, 2002, Dasar-dasar Pemasaran, Alih Bahasa Alexander Sindoro dan Benyamin Molan, Jakarta: Penerbit Prenhalindo. Jakarta: PT Bumi Aksara.

Istijanto, 2008, Riset Sumber Daya Manusia, Jakrta: Gramedia.

Arikunto, S. 2006, Metode Penelitian Kualitatif, Jakarta: Bumi Aksara.

Bungin, Burhan, 2003, Analisis Data Penelitian Kualitatif, Jakarta: PT Raja Grafindo Persada.
Bungin, Burhan, 2007, Penelitian Kualitatif; Komunikasi, Ekonomi, Kebijakan Publik, dan Ilmu Sosial Lainnya, Jakarta: Kencana Prenada Media Group.

Bungin, Burhan, 2006. Sosiologi Komunikasi: Teori, Paradigma dan Diskursus Teknologi Komunikasi di Masyarakat, Jakarta: Kencana Prenada Media Group. Selatan, 2018.

\section{UCAPAN TERIMA KASIH}

Terima kasih kami ucapkan kepada kampus STAI Yapnas Jeneponto karena telah memberikan penulis peluang untuk dapat mengirimkan tulisan ini sebagai perwakilan kampus tercinta. Terima kasih pula yang tidak terhingga kepada seluruh jajaran pihak Media Radar Selatan atas bantuan dan bersedia berkenan menjadi bagian dari penelitian ini. Semoga penelitian ini menjadi rujukan untuk dapat berkembang lebih baik lagi. Wassalam.. 